\title{
Growth performance, carcass and non-carcass characteristics of Mubende and MubendexBoer crossbred goats under different feeding regimes
}

Asizua, D.; Mpairwe, D.; Kabi, F.; Mutetikka, D.; Kamatara, K.; Hvelplund, Torben; Weisbjerg, Martin Riis; Mugasi, S.K.; Madsen, Jørgen

\section{Published in:}

Livestock Science

DOI:

10.1016/j.livsci.2014.09.010

Publication date:

2014

\section{Document version}

Early version, also known as pre-print

Citation for published version (APA):

Asizua, D., Mpairwe, D., Kabi, F., Mutetikka, D., Kamatara, K., Hvelplund, T., Weisbjerg, M. R., Mugasi, S. K., \& Madsen, J. (2014). Growth performance, carcass and non-carcass characteristics of Mubende and MubendexBoer crossbred goats under different feeding regimes. Livestock Science, 169, 63-70. https://doi.org/10.1016/j.livsci.2014.09.010 


\title{
Growth performance, carcass and non-carcass characteristics of Mubende and Mubende $\times$ Boer crossbred goats under different feeding regimes
}

\author{
D. Asizua ${ }^{\mathrm{a}, \mathrm{e}}$, D. Mpairwe ${ }^{\mathrm{a}, *}$, F. Kabi ${ }^{\mathrm{a}}$, D. Mutetikka ${ }^{\mathrm{a}}$, K. Kamatara ${ }^{\mathrm{a}}$, \\ T. Hvelplund ${ }^{\text {b }}$, M.R. Weisbjerg ${ }^{\text {b }}$, S.K. Mugasi ${ }^{\text {c }}$, J. Madsen ${ }^{\mathrm{d}}$ \\ ${ }^{a}$ Department of Agricultural Production, College of Agricultural and Environmental Sciences, Makerere University, P. O. Box 7062, \\ Kampala, Uganda \\ ${ }^{\mathrm{b}}$ Department of Animal Science, AU Foulum, Faculty of Science and Technology, Aarhus University, DK-8830 Tjele, Denmark \\ ${ }^{\mathrm{C}}$ Nyakahita Farm, Nyakashashara, Kiruhura, Uganda \\ ${ }^{\mathrm{d}}$ Department of Large Animal Sciences, Faculty of Health and Medical Sciences, University of Copenhagen, DK-1958 Frederiksberg C, \\ Denmark \\ ${ }^{\text {e }}$ Abi Zonal Agricultural Research and Development Institute, National Agricultural Research Organisation, P. O. Box 219, Arua, Uganda
}

\section{A R T I C L E I N F O}

\section{Article history:}

Received 26 March 2014

Received in revised form

5 September 2014

Accepted 9 September 2014

\section{Keywords:}

Grazing

Supplementation

Meat production

Mubende goat

Boer goat

\begin{abstract}
A B S T R A C T
A surge in the demand for goats' meat both locally and internationally has prompted many goat farmers in Uganda to venture into commercial goat production. However, goat production is highly challenged by breed characteristics and extreme fluctuations in feed quantity and quality. This study evaluated the effects of supplementing grazing Mubende goats and their crossbreds (Mubende $\times$ Boer) with concentrates on growth, carcass and noncarcass characteristics. A $2 \times 3$ factorial treatment arrangement was used to randomly allocate 96 pure Mubende and Mubende $\times$ Boer castrates (mean \pm SE; $31.3 \pm 2.2 \mathrm{~kg}$ initial weight) aged between 9 and 15 months, to three feeding regimes. The feeding regimes included (i) sole grazing (SGZ) as control, (ii) control+concentrate containing molasses (MCM) and (iii) control+concentrate without molasses (MCC). Concentrate dry matter intake was higher $(P<0.001)$ in the crossbreds regardless of concentrate type, however, inclusion of molasses resulted in lower concentrate intake. The Mubende goats were more efficient in utilising concentrate with molasses while the crossbreds utilised concentrate without molasses more efficiently. Average daily gain (ADG) was higher $(P<0.001)$ in the crossbreds and in the supplemented groups. Slaughter weight, empty body weight and hot carcass weight were also higher $(P<0.001)$ in the crossbreds than the pure Mubende. Supplementation reduced gut fill $(P<0.001)$ and increased $(P<0.001)$ hot carcass weight and dressing percentage in both genotypes. Proportion of non-carcass components as percentage of empty body weight did not vary between genotypes but supplementation reduced $(P<0.01)$ proportion of skin with hocks and empty stomach. Kidney fat, omental fat and scrotal fat increased $(P<0.001)$ with supplementation. Therefore, crossbreeding together with supplementation of grazing can considerably improve goat meat production, however, caution should be taken on the level of concentrate supplement offered as tendency for absolute substitution of concentrate for grass/browse by goats was observed in this study.
\end{abstract}

(c) 2014 Elsevier B.V. All rights reserved.

\footnotetext{
* Correspondence to: Department of Agricultural Production, School of Agricultural Sciences, Makerere University, P. O. Box 7062, Kampala, Uganda. Tel: +256 414532269 .

E-mail address: dmpairwe@agric.mak.ac.ug (D. Mpairwe).
} 


\section{Introduction}

Livestock production is among the top priority agricultural enterprises expected to contribute significantly to agricultural development in Uganda (MAAIF, 2010). Beef, dairy, goats and poultry production have continued to support the livelihoods of the predominantly smallholder communities in the country. Due to their higher reproductive prolificacy (i.e. twinning ability and short gestation period), small size and ease of disposal compared to the larger ruminants, goats provide a major source of income and animal proteins to many households. Uganda's goat population is estimated at 12.5 million of which $98.7 \%$ are indigenous and only about $1.0 \%$ are exotic meat genotypes and $0.3 \%$ exotic dairy (UBOS, 2009). An estimated 39\% of households in Uganda are known to own goats, which further demonstrates the importance of goats in the livelihoods of the people (UBOS, 2009).

An increase in demand for goat meat both locally and internationally (Juma et al., 2010; MAAIF, 2010) has prompted many farmers to venture into commercial goat production. However, commercial goat production is highly challenged by the existing breed characteristics and extreme fluctuations in feed quantity and quality. Natural pastures in the rangelands provide the major feed resource base for goat production in Uganda. The rangelands are characterised by high supply of good quality forage during the wet season but with a significant drop in both quantity and quality of forage during the dry season. These fluctuations often translate into inefficiencies in nutrient supply to the animals. Coupled with the rising human population and its associated pressure on land in Uganda, goat herd productivity based on natural pastures alone is bound to diminish. It has, therefore, become imperative to supplement grazing goats with protein and energy sources from locally available agro-industrial byproducts in order to improve the productive capacity of the existing goat genotypes in Uganda. However, supplementation of goats by farmers is still very limited due to paucity of information on the most appropriate supplementary feeds and modes of feeding.

It is known that supplementation of grazing goats significantly increases feed intake and digestibility of feeds with subsequent increase in growth rates and meat yield (Ben-Salem and Smith , 2008; Kawas et al., 2010). However, Caton and Dhuyvetter (1997) noted that energy supplementation in grazing animals may reduce forage intake. This study, therefore, evaluated the effects of supplementing grazing pure Mubende and Mubende $\times$ Boer crossbred goats with concentrate containing molasses and concentrate without molasses on growth rate, carcass and non-carcass characteristics and efficiency of concentrate utilisation.

\section{Materials and methods}

\subsection{Study area}

The study was conducted on-farm between August and November 2007 from wet to dry season in Kiruhura district, South Western Uganda. The study area lies within the cattle corridor of Uganda at an altitude of $1300 \mathrm{~m}$ and latitudes $1^{\circ} 0^{\prime \prime} 0^{\prime}$ North and $031^{\circ} 04^{\prime \prime} 34^{\prime}$ East. The area receives a total annual rainfall ranging from $800-1233 \mathrm{~mm}$. The total rainfall during the study year was $977 \mathrm{~mm}$. Temperatures in the area vary between $28{ }^{\circ} \mathrm{C}$ and $16{ }^{\circ} \mathrm{C}$ with lowest temperatures occurring during the wet season of July to August while highest temperatures occur during the dry season (November to March). Major grass species in the area include Brachiaria brizantha, Cymbopogon citratus, Themeda triandra, Panicum maximum, Chloris gayana, Sporobolus africanus and Laudetia spp. with Acacia nilotica as the most common leguminous shrub species.

\subsection{Experimental animals and treatments}

All the goats used in the study were purchased from Ruhengyere, a ranch under the National Animal Genetic Resources Centre and Data Bank about $20 \mathrm{~km}$ from the study location. Goats were stratified by weight into two groups within each genotype and randomly allotted to each of the three feeding regimes which comprised (i) sole grazing as control (SGZ), (ii) control plus supplementation with concentrate without molasses (MCC) and (iii) control plus supplementation with concentrate containing molasses (MCM). A $2 \times 3$ factorial treatment design was used to randomly allocate 96 castrated goats $(31.3 \pm 2.2 \mathrm{~kg}$ initial weight); 48 pure Mubende (MDE) and 48 Mubende-Boer $(\mathrm{M} \times \mathrm{B})$ crossbreds aged between 9 and 15 months, to the three feeding regimes. Concentrates were formulated and mixed on-farm from maize bran, cottonseed cake and molasses. Details of the proportions and nutrient composition of concentrates and pasture are presented in Table 1. Sixteen animals per genotype were assigned to each feeding regime and divided in two pens $(4 \times 3 \mathrm{~m})$ with each having eight goats. Each pen formed an experimental unit used for data collection on concentrate dry matter (DM) intake.

\subsection{Animal management}

Goats were treated for internal parasites using albendazole (10\%) drench on arrival at the farm. External parasites, mainly ticks which are endemic in the study area, were controlled through weekly hand spraying with Decatix (deltamethrin 5\% w/v) throughout the trial period. Goats were grazed between 10:00 and 18:00 h. Concentrates including an additional $10 \%$ of previous day's intake were offered overnight. Free access was allowed to water and rock salt within pens for MCC and MCM; and in shades for control group. The trial lasted for 104 days including a two weeks adaptation period during which goats were accustomed to confinement and supplements.

\subsection{Feed intake and body weight measurements}

Concentrates were weighed and offered every evening while refusals were weighed every morning per pen to estimate daily concentrate DM intake. Representative concentrate samples and refusals were taken weekly and pooled for chemical analysis. Although pasture DM intake was not directly determined, voluntary DM intake was estimated as 3.3\% of live body weight for growing goats, adopted from Luo et al. (2004c). Also, one of the voluntary 
Table 1

Ingredient and chemical composition and in vitro digestibility of feeds.

\begin{tabular}{llll}
\hline & MCC & MCM & Pasture \\
\hline Ingredients (g/kg DM) & & \\
Maize bran & 700 & 580 & - \\
Cottonseed cake & 300 & 220 & - \\
Molasses & - & 200 & - \\
Chemical composition (g/kg DM unless & stated) & \\
Dry matter & $835 \pm 15$ & $723 \pm 17$ & $450 \pm 42$ \\
Crude protein & $173 \pm 7$ & $164 \pm 6$ & $91 \pm 17$ \\
Ether extracts & $86 \pm 4$ & $82 \pm 4$ & $9.8 \pm 0.7$ \\
Crude fibre & $111 \pm 2$ & $103 \pm 6$ & $322 \pm 29$ \\
NDF & $517 \pm 18$ & $377 \pm 8$ & $558 \pm 41$ \\
ADF & $107 \pm 8$ & $108 \pm 8$ & $346 \pm 30$ \\
ADL & $101 \pm 7$ & $27 \pm 2$ & $109 \pm 11$ \\
Calcium & $0.9 \pm 0.3$ & $1 \pm 0.3$ & $6.8 \pm 0.7$ \\
Phosphorous & $11.5 \pm 0.3$ & $10.5 \pm 0.9$ & $4.7 \pm 0.5$ \\
Ash & $91 \pm 5$ & $76 \pm 8$ & $86 \pm 4$ \\
NFE & $554 \pm 15$ & $560 \pm 24$ & $491 \pm 23$ \\
in vitro OMD & $881 \pm 23$ & $859 \pm 14$ & $481 \pm 20$ \\
ME $^{\mathrm{c}}(\mathrm{MJ} / \mathrm{kg} \mathrm{DM})$ & $13.1 \pm 0.2$ & $12.9 \pm 0.4$ & $9.9 \pm 0.7$ \\
DE $^{\mathrm{d}}$ (MJ/kg DM) & 16.0 & 15.7 & 8.0 \\
ME $^{\mathrm{e}}$ (MJ/kg DM) & 12.8 & 12.6 & 6.4 \\
$\mathrm{NE}^{\mathrm{f}}$ (MJ/kg DM) & 9.2 & 9.0 & 2.4 \\
\hline
\end{tabular}

MCC - concentrate without molasses, MCM - concentrate with molasses

${ }^{a}$ Dry matter on as fed basis $(\mathrm{g} / \mathrm{kg})$.

${ }^{\mathrm{b}} \mathrm{OMD}$ - organic matter digestibility.

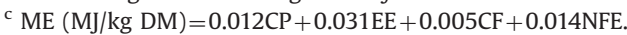

${ }^{\mathrm{d}} \mathrm{DE}(\mathrm{MJ} / \mathrm{kg} \mathrm{DM})=24.237 \times$ digestible crude protein $(\mathrm{kg} / \mathrm{kg} \mathrm{DM})+$ $34.116 \times$ digestible crude fat $(\mathrm{kg} / \mathrm{kg} \mathrm{DM})+17.300 \times$ digestible carbohydrates $(\mathrm{kg} / \mathrm{kg} \mathrm{DM})-0.766 \times$ sugar $(\mathrm{kg} / \mathrm{kg} \mathrm{DM})$. Where: digestible crude protein $(\mathrm{kg} / \mathrm{kg} \mathrm{DM})=0.93 \mathrm{~g}$ crude protein $/ \mathrm{kg} \mathrm{DM}-30$; digestible crude fat $(\mathrm{kg} / \mathrm{kg} \mathrm{DM})=0.96 \mathrm{~g}$ crude fat $/ \mathrm{kg} \mathrm{DM}-10$; digestible carbohydrates $(\mathrm{kg} / \mathrm{kg} \mathrm{DM})=($ digestibility of organic matter $/ 100) \times(1000-$ crude ash (g)-digestible crude protein-digestible crude fat).

e $\mathrm{ME}(\mathrm{MJ} / \mathrm{kg} \mathrm{DM})=\mathrm{DE} \times 0.8$.

${ }^{\mathrm{f}} \mathrm{NE}=\mathrm{SFU}$ (Scandinavian feed unit) $\times 7.8$ (SFUper $\mathrm{kg} \mathrm{DM}=-0.369+$ $0.0989 \times \mathrm{DE}(\mathrm{MJ} / \mathrm{kg} \mathrm{DM})-0.347 \times$ crude fibre $(\mathrm{g} / \mathrm{kg} \mathrm{DM}))$.

intake models $(\mathrm{DM}$ intake $=0.4605+0.0203 \times \mathrm{BW}+1.9815$ $\times$ ADG $-0.0387 \times$ metabolisable energy concentration) proposed by Luo et al. (2004c) for pen fed growing indigenous and crossbred meat goats was used to estimate the voluntary intake of the supplemented goats. Pasture samples were also collected each month through on-spot observation of the grazing/browsing behaviour of goats and samples were taken simulating herbage selected by goats at random sites in the grazing area.

Initial body weights of goats were determined by two consecutive days of weighing and subsequent weights were taken every 14 days. All weights were taken after an overnight fasting. Average daily gain was calculated from weight change within a given duration. Concentrate efficiency was calculated as the amount of concentrate consumed per unit of live weight gain.

\subsection{Measurements at slaughter}

At the end of the feeding period, 10 goats per treatment were randomly selected and slaughtered in two batches of 30 animals each. Five goats per treatment were slaughtered in each batch of slaughter. Goats were transported for about $10 \mathrm{~h}$ to a commercial abattoir located $300 \mathrm{~km}$ from the ranch and were slaughtered after an overnight fasting in a lairage with access to water. Each goat was weighed before slaughter to determine the slaughter live weight. Fasting loss was computed as the difference between final live weight at the farm and slaughter live weight. Hot carcass weights were taken immediately after slaughter and removal of non-carcass components. Weight of noncarcass components recorded included head, skin with hocks, heart, lungs with trachea, kidney, liver, full and empty stomach (rumen, reticulum, omasum and abomasum) and intestines (full and empty). Gut fill was calculated as the difference between full and empty stomach and intestines. Empty body weight was calculated as the difference between slaughter live weight and gut fill. Omental fat, mesenteric fat, kidney fat, pericardial fat and scrotal fat were also weighed and recorded. Dressing percentage was computed as a proportion of the hot carcass weight to the slaughter live weight and also as a proportion of empty body weight. The proportions of the different non-carcass components relative to the empty body weight were computed.

\subsection{Chemical analysis of feeds and calculation of energy values}

Concentrate and pasture samples were analysed for $\mathrm{DM}$, crude protein (CP), ether extracts (EE), calcium (Ca) and phosphorous $(\mathrm{P})$ and total ash according to the procedures of AOAC (1990). Neutral detergent fibre (NDF), acid detergent fibre (ADF), acid detergent lignin (ADL) and crude fibre were determined by the procedures of Van soest et al. (1991) with correction for residual ash. in vitro organic matter digestibility was determined following the method of Tilley and Terry (1963). Metabolisable energy (ME) contents of feeds were estimated from their chemical composition following the equation of MAFF (1975); $\quad \mathrm{ME} \quad(\mathrm{MJ} / \mathrm{kg} \quad \mathrm{DM})=0.012 \mathrm{CP}+0.031 \mathrm{EE}+$ $0.005 \mathrm{CF}+0.014 \mathrm{NFE}$. The contents of digestible energy (DE) and net energy (NE (Scandinavian feed units (SFU)) were determined based on the chemical composition and the in vitro digestibility of organic matter according to Weisbjerg and Hvelplund (1993). Scandinavian feed units (SFU $=7.89 \mathrm{MJ} / \mathrm{kg} \mathrm{DM}$ ) was estimated as SFU per $\mathrm{kg}$ $\mathrm{DM}=-0.369+0.0989 \times$ digestible energy $(\mathrm{MJ} / \mathrm{kg} \mathrm{DM})-$ $0.347 \times$ crude fibre $(\mathrm{kg} / \mathrm{kg} \mathrm{DM})$. Digestible energy $(\mathrm{MJ} / \mathrm{kg}$ $\mathrm{DM})$ was estimated as; $\mathrm{DE} \quad(\mathrm{MJ} / \mathrm{kg} \quad \mathrm{DM})=24.237 \times$ digestible crude protein $(\mathrm{kg} / \mathrm{kg} \mathrm{DM})+34.116 \times$ digestible crude fat $(\mathrm{kg} / \mathrm{kg} \mathrm{DM})+17.300 \times$ digestible carbohydrates $(\mathrm{kg} / \mathrm{kg} \mathrm{DM})-0.766 \times$ sugar $(\mathrm{kg} / \mathrm{kg} \mathrm{DM})$. Where: digestible crude protein $(\mathrm{kg} / \mathrm{kg} \quad \mathrm{DM})=0.93 \mathrm{~g}$ crude protein $/ \mathrm{kg}$ $\mathrm{DM}-30$; digestible crude fat $(\mathrm{kg} / \mathrm{kg} \mathrm{DM})=0.96 \mathrm{~g}$ crude fat $/ \mathrm{kg} \mathrm{DM-10;} \mathrm{digestible} \mathrm{carbohydrates}(\mathrm{kg} / \mathrm{kg} \mathrm{DM})=$ (digestibility of organic matter/100) $\times(1000$-crude ash (g)-digestible crude protein-digestible crude fat). The correction for sugar was made only for feeds where the sugar content exceeded $20 \%$ of the DM content. Chemical composition and calculation of energy values of feeds are presented in Table 1.

\subsection{Statistical analysis}

Data was analysed using the general linear model (GLM) procedures of Statistical Analysis Systems (SAS, 2001). 
Factors included in the model were genotype, diet and genotype and diet interactions in a factorial structure. The least square means generated were separated using the probability of difference option. The lowest standard error of the mean was used in case they were different.

\section{Results}

\subsection{Feed intake, growth rate and concentrate use per $\mathrm{kg}$ weight gain}

Chemical compositions (Table 1) and in vitro digestibility showed that the energy value and crude protein (CP) content of the concentrates were much higher than that of the samples from the grazed pasture. Although the pasture was low in digestibility, the protein content was higher than what is often observed in natural pastures.

Concentrate DM and subsequently $\mathrm{CP}, \mathrm{ME}$ and NE intake were higher $(P<0.001)$ in the crossbreds regardless of type of concentrate (Table 2). For both genotypes, concentrate without molasses resulted in higher $(P<0.001)$ DM intake than concentrate with molasses. Overall concentrate dry matter intake ranged between 0.83 and $1.37 \mathrm{~kg}$ DM while predicted voluntary total DM intakes ranged between 1.06 and $1.21 \mathrm{~kg}$.

Live body weight was higher $(P<0.01)$ in the crossbreds than the pure Mubende throughout the feeding period while whole period weight gain was higher $(P<0.001)$ in the supplemented groups (Table 2$)$. The average daily gain (ADG) was similar for all feeding regimes in the first month of feeding, however, in the second $(P<0.05)$ and third $(P<0.001)$ months the supplemented goats had higher ADG than control goats on sole grazing (Table 2). The concentrate conversion per $\mathrm{kg}$ weight gain was between 8.1 and $11.9 \mathrm{~kg}$ DM with significant $(P<0.001)$ genotype and feeding regime interaction effects. The Mubende goat genotype was more efficient in utilising concentrate with molasses while the crossbred genotype utilised concentrate without molasses more efficiently.

\subsection{Carcass and non-carcass characteristics}

Supplementation resulted in higher slaughter weight $(P<0.05)$, empty body weight $(P<0.001)$, carcass weight $(P<0.01)$ and carcass dressing as percentage of slaughter weight $(P<0.001)$, regardless of genotype (Table 3$)$. Fasting loss was numerically higher in the sole grazing animals, although effects of both genotype and feeding regime were not significant. Meanwhile, gut fill was lower $(P<0.001)$ in the supplemented groups than in the sole grazing except in the crossbreds fed concentrate containing molasses where gut fill was similar to sole grazing. Slaughter components generally followed live weight differences between genotypes and were therefore higher in the crossbreds.

Non-carcass components as percentage of empty body weight did not vary between genotypes (Table 4). Supplementation resulted in lower proportion of skin with hocks $(P<0.01)$ and empty stomach $(P<0.001)$ with the lowest proportions observed in all genotypes fed on MCC.
Meanwhile, higher proportion of kidney fat $(P<0.001)$, omental fat $(P<0.001)$ and scrotal fat $(P<0.001)$ were observed in the supplemented groups regardless of the type of supplement. In the pure Mubende, proportions of kidney fat in supplemented groups were more than triple the proportion found in the solely grazing animals, and nearly the same effect was found for omental fat. Numerically higher proportions of kidney, omental and scrotal fats were observed in the supplemented pure Mubende than the crossbreds.

\section{Discussion}

\subsection{Concentrate dry matter utilisation}

The observed concentrate DM intakes in this study were similar to total DM intakes for growing meat goats of similar live weight and average daily gain reported by Sahlu et al. (2004) and Luo et al. (2004c) and in Boer and Kiko goats as reported by Solaiman et al. (2012). Crude protein and ME intakes were also within the ranges reported by Luo et al., (2004a) and Luo et al., (2004b) for growing meat goats and Patra et al. (2008) in Boer $\times$ Spanish goats. The concentrate intakes of the supplemented goats implied that concentrates accounted for almost all net energy intakes and the browsed/grazed material only supplied a minimal structural part of the total diets. The results also indicated that inclusion of $20 \%$ molasses into concentrate improved concentrate DM utilisation. However, the substitution rate between concentrate and grass/browse intake by the goats is considered high as concentrate intake seemed to be high accounting for the entire and expected total voluntary intake of growing meat goats (Luo et al., 2004c). The higher intake of concentrate without molasses compared to concentrate with molasses explains the influence of protein and energy on intake of goats as previously reported by $\mathrm{Lu}$ and Potchoiba (1990) who showed that DM intake of goats increased linearly with increasing content of protein while higher energy content in feed tended to decrease intake. Depression in concentrate DM intake by inclusion of molasses in diets was possibly due to the presence of more ruminally degradable and therefore readily available energy provided by this agro industrial by product than by concentrate without it which is in agreement with Caton and Dhuyvetter (1997) who observed that intake and digestibility can either be reduced or remain unaffected by energy supplementation. The reduced intake due to inclusion of molasses is also consistent with the energy intake regulatory theory which postulates that ruminants appear to consume feed to meet their energy requirements (NRC, 1991), although, the estimated energy values of MCC according to both MAFF (1975) and Weisbjerg and Hvelplund (1993) was lower for concentrate with molasses. The efficiency of concentrate utilisation of $8.1-11.9 \mathrm{~kg} \mathrm{DM} / \mathrm{kg}$ live weight gain is comparable to the amount used to obtain one kg weight gain in non-grazing cattle (Mwilawa, 2012). However, this is much higher than the efficiency of feed utilisation of $3.4 \mathrm{~kg}$ DM per $\mathrm{kg}$ live weight observed by Haddad (2005) in Baladi goat kids fed diet containing $85 \%$ concentrate. The higher concentrate 
Table 2

Effects of genotype and feeding regime on concentrate DM and CP intake, initial and final weight, average daily gain and efficiency of concentrate utilisation.

\begin{tabular}{|c|c|c|c|c|c|c|c|c|c|c|}
\hline & \multicolumn{3}{|l|}{ MDE } & \multicolumn{3}{|l|}{$\mathrm{M} \times \mathrm{B}$} & \multirow[t]{2}{*}{ SEM } & \multicolumn{3}{|c|}{ Significance } \\
\hline & $\operatorname{SGZ}(n=16)$ & $\operatorname{MCC}(n=16)$ & $\operatorname{MCM}(n=16)$ & $\operatorname{SGZ}(n=16)$ & $\operatorname{MCC}(n=16)$ & $\operatorname{MCM}(n=16)$ & & G & $\mathrm{F}$ & $G \times F$ \\
\hline \multicolumn{11}{|l|}{ Concentrate intake } \\
\hline DM (kg/day) & 0 & $1.11^{\mathrm{b}}$ & $0.83^{d}$ & 0 & $1.37^{\mathrm{a}}$ & $1.06^{\mathrm{c}}$ & 0.02 & $* * *$ & $* * * *$ & ns \\
\hline Total DM (kg/90 days) & 0 & $100.7^{b}$ & $74.8^{d}$ & 0 & $123.8^{\mathrm{a}}$ & $95.6^{\mathrm{c}}$ & 1.5 & $* * *$ & $* * *$ & ns \\
\hline $\mathrm{CP}$ intake (g/day) & 0 & $232^{\mathrm{c}}$ & $189^{d}$ & 0 & $285^{\mathrm{a}}$ & $241^{b}$ & 3.6 & $* * *$ & $* * * *$ & ns \\
\hline ME intake (MJ/day) & 0 & $14.3^{\mathrm{b}}$ & $10.5^{\mathrm{d}}$ & 0 & $17.6^{\mathrm{a}}$ & $13.3^{c}$ & 0.22 & $* * *$ & $* * * *$ & ns \\
\hline NE intake (MJ/day) & 0 & $10.3^{\mathrm{b}}$ & $7.48^{\mathrm{d}}$ & 0 & $12.7^{\mathrm{a}}$ & $9.6^{\mathrm{c}}$ & 0.16 & $* * *$ & $* * * *$ & ns \\
\hline Initial body weight (kg) & 28.2 & 27.4 & 28 & 29.8 & 30.1 & 29.8 & 1.2 & ns & ns & ns \\
\hline Final body weight (kg) & $34.6^{\mathrm{b}}$ & $37.4^{\mathrm{b}}$ & $37.7^{\mathrm{b}}$ & $37.5^{\mathrm{b}}$ & $42.3^{\mathrm{a}}$ & $41.8^{\mathrm{ab}}$ & 1.5 & $* *$ & $*$ & ns \\
\hline \multicolumn{11}{|l|}{ Average daily gain (g/day) } \\
\hline Overall & $70^{\mathrm{d}}$ & $110^{\mathrm{bc}}$ & $110^{\mathrm{bc}}$ & $100^{\mathrm{cd}}$ & $160^{\mathrm{a}}$ & $140^{\mathrm{ab}}$ & 10 & $* * *$ & $* * * *$ & ns \\
\hline $0-28$ days & 80 & 80 & 80 & 120 & 120 & 120 & 20 & ns & ns & ns \\
\hline $28-56$ days & $70^{\mathrm{b}}$ & $110^{\mathrm{ab}}$ & $120^{\mathrm{ab}}$ & $80^{\mathrm{b}}$ & $140^{\mathrm{a}}$ & $130^{\mathrm{ab}}$ & 20 & ns & $*$ & ns \\
\hline 56-90 days & $60^{\mathrm{b}}$ & $120^{\mathrm{a}}$ & $120^{\mathrm{a}}$ & $60^{\mathrm{b}}$ & $140^{\mathrm{a}}$ & $150^{\mathrm{a}}$ & 20 & ns & $* * * *$ & ns \\
\hline $\mathrm{FCR}^{1}, \mathrm{~kg} \mathrm{DM} / \mathrm{kg}$ live weight gain & ns & $11.9^{\mathrm{a}}$ & $8.1^{\mathrm{d}}$ & ns & $10.5^{b}$ & $9.5^{\mathrm{c}}$ & 0.2 & ns & $* * * * *$ & $* * *$ \\
\hline \multicolumn{11}{|l|}{ Predicted DMI, kg/day } \\
\hline DMI, (3.3\% BW) & $1.08^{\mathrm{cd}}$ & $1.06^{\mathrm{d}}$ & $1.10^{\mathrm{c}}$ & $1.17^{\mathrm{b}}$ & $1.21^{\mathrm{a}}$ & $1.19^{\mathrm{ab}}$ & 0.007 & $* * *$ & ns & $* *$ \\
\hline $\mathrm{DMI}^{2}$, (Luo et al., 2004c) & & $0.81^{\mathrm{d}}$ & $0.89^{c}$ & & $1.03^{\mathrm{a}}$ & $0.98^{\mathrm{b}}$ & 0.005 & $* * *$ & ns & $* * * *$ \\
\hline
\end{tabular}

Interaction effect was only significant for concentrate efficiency $(P<0.001)$.

ns - non significant.

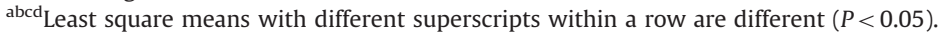

SGZ - Sole grazing (Control), MCC - Grazing plus supplementation with concentrate without molasses, MCM - Grazing plus concentrate containing molasses, SEM - standard error of the mean.

${ }^{1} \mathrm{FCR}_{\mathrm{c}}$ - Feed conversion ratio of concentrate.

2 DMI-Predicted voluntary DM intake according to Luoet al., 2004c (DM intake $=0.4605+0.0203 \times$ BW $+1.9815 \times$ ADG $-0.0387 \times$ metabolisable energy concentration).

$* P<0.05$.

*** $P<0.01$.

**** $P<0.001$

Table 3

Slaughter characteristics as affected by genotype and feeding regime.

\begin{tabular}{|c|c|c|c|c|c|c|c|c|c|}
\hline & \multicolumn{3}{|l|}{ MDE } & \multicolumn{3}{|l|}{$\mathrm{M} \times \mathrm{B}$} & \multirow[t]{2}{*}{ SEM } & \multicolumn{2}{|c|}{ Significance } \\
\hline & $\operatorname{SGZ}(n=10)$ & $\operatorname{MCC}(n=10)$ & $\operatorname{MCM}(n=10)$ & $\operatorname{SGZ}(n=10)$ & $\operatorname{MCC}(n=10)$ & $\operatorname{MCM}(n=10)$ & & Genotype & Feeding \\
\hline Slaughter weight $(\mathrm{kg})$ & $34.7^{c}$ & $37.4^{\mathrm{c}}$ & $37.7^{\mathrm{c}}$ & $38.8^{\mathrm{bc}}$ & $43.9^{\mathrm{a}}$ & $41.9^{\mathrm{ab}}$ & 1.4 & $* * * *$ & $*$ \\
\hline Fasting loss (\%) & 6.2 & 5.8 & 4.2 & 6.5 & 5.5 & 4.9 & 1.3 & ns & ns \\
\hline Gut fill (kg) & $4.2^{\mathrm{a}}$ & $2.7^{\mathrm{b}}$ & $3.2^{\mathrm{b}}$ & $4.4^{\mathrm{a}}$ & $3.2^{\mathrm{b}}$ & $4.3^{\mathrm{a}}$ & 0.3 & $*$ & **** \\
\hline EBW (kg) & $30.4^{\mathrm{c}}$ & $35.1^{b}$ & $34.4^{\mathrm{b}}$ & $34.4^{\mathrm{b}}$ & $40.3^{a}$ & $37.6^{\mathrm{ab}}$ & 1.4 & $* * * *$ & $* *$ \\
\hline Carcass weight (kg) & $17.4^{\mathrm{d}}$ & $20.7^{\mathrm{bc}}$ & $19.9^{c}$ & $19.9^{c}$ & $23.6^{\mathrm{a}}$ & $22.0^{\mathrm{ab}}$ & 0.7 & $* * *$ & $* * *$ \\
\hline Dressing $^{1}(\%)$ & $50.3^{d}$ & $55.4^{\mathrm{a}}$ & $52.8^{\mathrm{b}}$ & $51.3^{\mathrm{cd}}$ & $53.7^{\mathrm{ab}}$ & $52.5^{\mathrm{bc}}$ & 0.6 & ns & $* * *$ \\
\hline Dressing $^{2}(\%)$ & 57.7 & 59.5 & 57.8 & 58 & 57.7 & 58.5 & 0.6 & ns & ns \\
\hline
\end{tabular}

ns - non significant, Interaction effects were not significant and therefore not included in the table.

${ }^{\mathrm{ab}}$ Least square means with different superscripts within a row are different $(P<0.05)$, SGZ - Sole grazing (Control), MCC - Grazing plus supplementation with concentrate without molasses, MCM - Grazing plus concentrate containing molasses, SEM - standard error of the mean, EBW - Empty body weight.

${ }^{1}$ Dressing as percentage of slaughter weight,

2 Dressing as percentage of empty body weight.

* $P<0.05$.

*** $P<0.01$

**** $P<0.001$.

DM intake of the crossbreds $(\mathrm{M} \times \mathrm{B})$ which had a higher growth rate compared to the pure Mubende was in agreement with earlier results ( NRC, 1991) that animals take in DM to meet their energy demands for physiological functions such as growth and milk production. Preston and Leng (1987) noted that in the absence of environmental and nutritional constraints, DM intake is determined by genetic potential of the animal. This might have been the case for the supplemented goats in this experiment.

\subsection{Growth characteristics}

The growth rates of both the grazing goats and supplemented goats were higher than those earlier reported in 
Table 4

Effects of genotype and feeding regime on the distribution of non-carcass components as percentage of empty body weight.

\begin{tabular}{|c|c|c|c|c|c|c|c|c|c|}
\hline & \multicolumn{3}{|l|}{ MDE } & \multicolumn{3}{|l|}{$\mathrm{MxB}$} & \multirow[t]{2}{*}{ SEM } & \multicolumn{2}{|c|}{ Significance } \\
\hline & $\operatorname{SGZ}(n=10)$ & $\operatorname{MCC}(n=10)$ & $\operatorname{MCM}(n=10)$ & $\operatorname{SGZ}(n=10)$ & $\operatorname{MCC}(n=10)$ & $\operatorname{MCM}(n=10)$ & & Genotype & Feeding \\
\hline Head & 7.0 & 6.0 & 6.9 & 7.0 & 6.2 & 6.5 & 0.4 & ns & ns \\
\hline Skin with hocks & $12.9^{\mathrm{a}}$ & $10.8^{\mathrm{b}}$ & $12.4^{\mathrm{ab}}$ & $13.0^{\mathrm{a}}$ & $11.1^{\mathrm{b}}$ & $11.6^{\mathrm{ab}}$ & 0.6 & ns & $* *$ \\
\hline Empty stomach & $4.2^{\mathrm{ab}}$ & $3.7^{\mathrm{bc}}$ & $3.9^{\mathrm{abc}}$ & $4.5^{\mathrm{a}}$ & $3.5^{c}$ & $3.8^{\mathrm{bc}}$ & 0.2 & ns & $* * * *$ \\
\hline Empty intestines & 5.5 & 6.2 & 6.5 & 5.2 & 6.1 & 5.6 & 0.5 & ns & ns \\
\hline Liver & 2.3 & 2.2 & 2.5 & 2.4 & 2.2 & 2.4 & 0.1 & ns & ns \\
\hline Lungs with trachea & 1.9 & 1.9 & 2.0 & 1.9 & 1.8 & 1.7 & 0.1 & ns & ns \\
\hline Spleen & 0.2 & 0.2 & 0.3 & 0.3 & 0.3 & 0.3 & 0.03 & ns & ns \\
\hline Heart & 0.6 & 0.7 & 0.7 & 0.7 & 0.7 & 0.6 & 0.1 & ns & ns \\
\hline Kidney & 0.3 & 0.3 & 0.4 & 0.4 & 0.3 & 0.4 & 0.03 & ns & ns \\
\hline Pericardial fat & 0.2 & 0.2 & 0.2 & 0.2 & 0.2 & 0.2 & 0.02 & ns & ns \\
\hline Kidney fat & $0.5^{\mathrm{b}}$ & $1.8^{\mathrm{a}}$ & $1.8^{\mathrm{a}}$ & $0.6^{\mathrm{b}}$ & $1.4^{\mathrm{a}}$ & $1.5^{\mathrm{a}}$ & 0.3 & ns & $* * * *$ \\
\hline Omental fat & $1.4^{\mathrm{c}}$ & $4.4^{\mathrm{a}}$ & $4.0^{\mathrm{ab}}$ & $1.3^{c}$ & $4.3^{\mathrm{ab}}$ & $3.2^{\mathrm{b}}$ & 0.4 & ns & $* * * *$ \\
\hline Mesenteric fat & 1.8 & 1.9 & 2.0 & 1.4 & 2.0 & 1.3 & 0.3 & ns & ns \\
\hline Scrotal fat & $0.3^{\mathrm{b}}$ & $0.6^{\mathrm{a}}$ & $0.6^{\mathrm{a}}$ & $0.3^{\mathrm{b}}$ & $0.5^{\mathrm{a}}$ & $0.5^{\mathrm{a}}$ & 0.05 & ns & $* * * *$ \\
\hline
\end{tabular}

Interaction effects were not significant and therefore not included in the table.

ns - non significant.

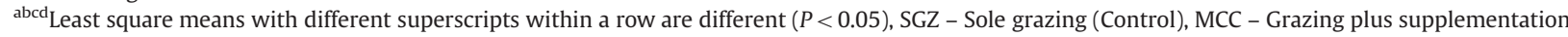
with concentrate without molasses, MCM - Grazing plus concentrate containing molasses, SEM - standard error of the mean, na - not applicable. ** $P<0.01$. **** $P<0.001$.

Uganda (Ssewanyana et al., 2004). This was probably because the grazing area in this experiment had higher quality pastures and browse in terms of protein content. However, the measured digestibility of sampled herbage was lower than anticipated possibly because of high levels of lignifications. Inefficiencies of simulating the exact herbage that was selected by the goats compared to materials selected for laboratory analysis could possibly have contributed to the observed lower in vitro digestibility. Nonetheless, the increase in average daily gain (ADG) resulting from concentrate intake was considerable especially in the last 34 (56-90) days of the trial where growth rate of the supplemented goats was more than double that of the control goats. Meanwhile, the overall increase in ADG of more than 57\% observed in both genotypes was higher than the $18 \%$ increment reported by Turner et al. (2014) in Boer-crossbreds but similar to observations made by Haddad (2005) on growing Baladi goats fed varying proportions of forage to concentrate.

The higher growth rate of $\mathrm{M} \times \mathrm{B}$ crossbreds showed the genetic superiority of the Boer goat over the pure Mubende goat and this was consistent with previously reported results by Ssewanyana et al. (2004). Various studies have also demonstrated superiority in growth rate of the Boer goat genotype over their crossbreds with other goat genotypes (Cameron et al., 2001; Dhanda et al., 2003; Negesse et al., 2007). However, as shown by goats fed concentrate, the superior growth rate of $\mathrm{M} \times \mathrm{B}$ crossbreds was mainly caused by a higher feed intake and to a lesser extent by an increased efficiency in utilisation of the concentrate (Table 2).

\subsection{Carcass and non-carcass characteristics}

The observed higher slaughter live weight, empty body weight and carcass weight of the Boer crossbreds were in agreement with results from other studies (Oman et al., 2000; Cameron et al., 2001; Herold et al., 2007). However, dressing percentage did not differ between the pure Mubende and the Boer crossbreds contrary to Dhanda et al. (2003) who observed differences in dressing percentages among crossbreds of Boer with Angora, Feral and Saanen genotypes and Herold et al. (2007) who observed difference in dressing percentages with Cashmere $x$ (Boer $\times$ German Fawn) crossbreds. This implied that, the proportions of carcass, non-carcass components and gut fill are similar between the pure Mubende and the crossbreds with Boer. Shadnoush et al. (2004) noted that the different carcass parts determine the relative merits of different breeds for meat production. This study, therefore, demonstrated the potential of the pure Mubende goat for meat production which can be considerably improved through crossbreeding with the Boer.

A positive contribution of concentrate supplementation to meat yield of grazing goats was demonstrated in this study. Both concentrates increased empty body weight, carcass weight and dressing percentage of the two goat genotypes. Increased carcass weights resulting from different levels of concentrates offered to goats have been reported by Okello et al. (1994) in Mubende goats, Ryan et al. (2007) in Boer goats, Mushi et al. (2009) and Safari et al. (2009) in the Small East African goats and their crossbreds with Norwegian goats. Mahgoub et al. (2005) also showed an increased slaughter weight, carcass weight, empty body weight and dressing percentage with increasing level of metabolisable energy in the diets of Omani goats. Similar findings were also reported by Solomon et al. (2008) in Sidama goats. The increased proportions of these components suggest a decreased proportion of non-carcass components at higher body weights. Kamalzadeh et al. (1998) noted that non-carcass components such as feet, head and visceral organs 
decreased with increasing body weight of sheep. This implies that at higher nutrient supply, the non-carcass components mature earlier and that any additional gain in body weight is attributed to carcass weight and other tissues such as fats. The considerable increase in noncarcass fat with supplementation was probably partly responsible for the relatively low live weight gain per $\mathrm{kg}$ of concentrate. Supplementation compared to sole grazing increased non-carcass fat (pericardial, kidney, omental, mesenteric, scrotal) with 2.9-4.7 as percent-units of empty body weight. Increase in internal and carcass fat in goats due to increasing intake of energy in diets has been reported by various authors (Goetsch et al., 2011; Zervas and Tsiplakou, 2011). As fat is nearly water free and high in energy density, this is enormous energy storage, with low slaughter value but very important as energy storage for the goat. A lowered weight of gut fill due to supplementation also contributed to the higher dressing percentage in supplemented goats. The study shows that the proportion of meat in the carcass of grazing Mubende goat and its crossbred with the Boer can be considerably improved through supplementation with concentrate.

Non-carcass components as percentage of empty body weight did not differ between the pure Mubende and their crossbreds. This demonstrated that the genotypes have similar patterns of nutrient partitioning between different body parts. This was also confirmed by the similar dressing percentages of the two genotypes (Table 3). Concentrate supplementation reduced the proportion of skin with hocks and empty stomach while the proportions of kidney fat, omental fat and scrotal fat increased with supplementation as previously observed by Zervas and Tsiplakou (2011). This confirms observations b,y Kamalzadeh et al. (1998) who reported early maturation of skin, hocks and viscera but late maturation of fat deposits. The proportions of internal fats and scrotal fat of Mubende goats observed in this study were higher than those observed by Mushi et al. (2009) in Small East African goats. Although this difference partly could be attributed to age differences, it indicated that the Mubende goats are distinctly different from other Small East African goats, the group under which the Mubende has often been classified. The observed proportions of internal fat (kidney, omental and mesenteric fats) in the concentrate supplemented goats were much lower than those observed by Ngwa et al. (2009) in Boer (3/4) $\times$ Spanish (1/4) and Spanish goats fed a pelleted $50 \%$ concentrate diet. However, goats fed a diet based on hay (Ngwa et al., 2009) had similar proportions of internal fat as the grazing goats observed in this study.

\section{Conclusion}

Concentrate supplementation of grazing offers a reliable option for improving meat production of the pure Mubende goat and its crossbred with the Boer; however, caution should be taken on the amount of supplement offered as tendency for absolute substitution of concentrate for grass/browse by goat was observed in this study. Meanwhile, the response of grazing pure Mubende goat to concentrate supplement is comparable to that of its crossbred with the Boer. However, the Boer crossbred exhibited better growth rate and meat yield than the pure
Mubende. Therefore, crossbreeding together with supplementation of grazing can considerably improve goat meat production in Uganda.

\section{Conflict of Interest}

No known conflict of interest.

\section{Acknowledgement}

This study was funded by DANIDA-ENRECA project IGMAFU-meat.

\section{References}

AOAC (Association of Official Analytical Chemists), 1990. In: Official Methods of Analysis15th Ed. AOAC Inc., Arlington, Virginia 22201 USA.

Ben-Salem, H., Smith, T., 2008. Feeding strategies to increase small ruminant production in dry environments. Small Rumin. Res. 77, $174-194$

Cameron, M.R., Luo, J., Sahlu, T., Hart, S.P., Coleman, S.W., Goetsch, A.L., 2001. Growth and slaughter traits of Boer $\times$ Spanish, Boer $\times$ Angora, and Spanish goats consuming a concentrate-based diet. J. Anim. Sci. 79, 1423-1430.

Caton, J.S., Dhuyvetter, D.V., 1997. Influence of energy supplementation on grazing ruminants: requirements and responses. J. Anim. Sci. 75, 533-542.

Dhanda, J.S., Taylor, D.G., Murray, P.J., 2003. Part 1. Growth, carcass and meat quality parameters of male goats: effects of genotype and live weight at slaughter. Small Rumin. Res. 50, 57-66.

Goetsch, A.L., Merkel, R.C., Gipson, T.A., 2011. Factors affecting goat meat production and quality. Small Rumin. Res. 101, 173-181.

Haddad, S.G., 2005. Effect of dietary forage:concentrate ratio on growth performance and carcass characteristics of growing Baladi kids. Small Rumin. Res. 57, 43-49.

Herold, P., Snell, H., Tawfik, E.S., 2007. Growth, carcass and meat quality parameters of purebred and crossbred goat kids in extensive pasture. Arch. Tierz. 50, 186-196.

Juma, G.P., Ngigi, M., Baltenweck, I., Drucker, A.G., 2010. Consumer demand for sheep and goat meat in Kenya. Small Rumin. Res. 90, 135-138.

Kamalzadeh, A., Koops, W.J., van Bruchem, J., Tamminga, S., Zwart, D., 1998. Feed quality restriction and compensatory growth in growing sheep: development of body organs. Small Rumin. Res. 29, 71-82.

Kawas, J.R., Andrade-Montemayor, H., Lu, C.D., 2010. Strategic nutrient supplementation of free-ranging goats. Small Rumin. Res. 89, 234-243.

Lu, C.D., Potchoiba, M.J., 1990. Feed intake and weight gain of growing goats fed diets of various energy and protein levels. J Anim Sci. 68, 1751-1759.

Luo, J., Goetsch, A.L., Nsahlai, I.V., Johnson, Z.B., Sahlu, T., Moore, J.E., Ferrell, C.L., Galyean, M.L., Owens, F.N., 2004a. Maintenance energy requirements of goats: predictions based on observations of heat and recovered energy. Small Rumin. Res. 53, 221-230.

Luo, J., Goetsch, A.L., Nsahlai, I.V., Moored, J.E., Galyean, M.L., Johnson, Z.B., Sahlu, T., Ferrell, C.L., Owens, F.N., 2004c. Voluntary feed intake by lactating Angora, growing and mature goats. Small Rumin. Res. 53, 357-378.

Luo, J., Goetsch, A.L., Nsahlai, I.V., Sahlu, T., Ferrell, C.L., Owens, F.N., Galyean, M.L., Moore, J.E., Johnson, Z.B., 2004b. Metabolizable protein requirements for maintenance and gain of growing goats. Small Rumin. Res. 53, 309-326.

MAAIF (Ministry Of Agriculture, Animal Industry and Fisheries), 2010. Agriculture Sector Development Strategy and Investment Plan: 2010/11-2014/15. Government of Uganda.

MAFF, 1975. Energy allowances and feeding systems for ruminants. Minist. Agric. Fish. Food Technol. Bull, 33.

Mahgoub, O., Lu, C.D., Hameed, M.S., Richie, A., Al-Halhali, A.S., Annamalai, K., 2005. Performance of Omani goats fed diets containing various metabolizable energy densities. Small Rumin. Res. 58, 175-180.

Mushi, D.E., Safari, J., Mtenga, L.A., Kifaro, G.C., Eik, L.O., 2009. Growth and distribution of non-carcass components of small East African and 
F1Norwegian crossbred goats under concentrate diets. Livest. Sci. $126,80-86$

Mwilawa, A.J.T., 2012. Effects of different diets on weight gain, carcass and meat quality characteristics of two indigenous cattle breeds of Tanzania (Ph.D. thesis). Sokoine University of Agriculture, Morogoro, Tanzania245.

Negesse, T., Patra, A.K., Dawson, L.J., Tolera, A., Merkel, R.C., Sahlu, T., Goetsch, A.L., 2007. Performance of Spanish and Boer $\times$ Spanish doelings consuming diets of different level of broiler litter. Small Rumin. Res. 69, 187-197.

Ngwa, A.T., Dawson, L.J., Puchala, R., Detweiler, G.D., Merkel, R.C., Wang, Z. Tesfai, K., Sahlu, T., Ferrell, C.L., Goetsch, A.L., 2009. Effects of breed and diet on growth and body composition of crossbred Boer and Spanish wether goats. J. Anim. Sci. 87, 2913-2923.

NRC, 1991. Nutrient Requirements of Dairy Cattle, Sixth Revised Edition National Academy Press, Washington, DC.

Okello, K.L., Ebong, C., Opuda-Asibo, J., 1994. Effect of feed supplements on weight gain and carcass characteristics of intact male Mubende goats fed elephant grass (Pennisetum purpureum) ad libitum in Uganda. Small Ruminant Research and Development in Africa. FAO corporate document repository.

Oman, J.S., Waldron, D.F., Griffin, D.B., Savell, J.W., 2000. Carcass traits and retail display-life of chops from different goat breed types. J. Anim. Sci. 78, 1262-1266.

Patra, A.K., Puchala, R., Detweiler, G., Dawson, L.J., Sahlu, T., Goetsch, A.L. 2008. Technical note: effects of tethering on herbage selection, intake and digestibility, grazing behavior, and energy expenditure by Boer $\times$ Spanish goats grazing high-quality herbage. J. Anim. Sci. 86 1245-1253.

Preston, T.R., Leng, R.A., 1987. Matching ruminant production systems with available resources in the tropics and sub-tropics. Penambul Books, Armidale.

Ryan, S.M., Unruh, J.A., Corrigan, M.E., Drouillard, J.S., Seyfert, M., 2007. Effects of concentrate level on carcass traits of Boer crossbred goats. Small Rumin. Res. 73, 67-76.

Safari, J., Mushi, D.E., Mtenga, L.A., Kifaro, G.C., Eik, L.O., 2009. Effects of concentrate supplementation on carcass and meat quality attributes of feedlot finished Small East African goats. Livest. Sci. 125, 266-274.
Sahlu, T., Goetsch, A.L., Luo, J., Nsahlai, I.V., Moore, J.E., Galyean, M.L. Owens, F.N., Ferrell, C.L., Johnson, Z.B., 2004. Nutrient requirements of goats: developed equations, other considerations and future research to improve them. Small Rumin. Res. 53, 191-219.

SAS, 2001. Statistical Analysis System, User's guide, version 8.2. SAS Institute Inc., Cary, NC, USA.

Shadnoush, G.H., Ghorbani, G.R., Edris, M.A., 2004. Effect of different energy levels in feed and slaughter weights on carcass and chemical composition of Lori-Bakhtiari ram lambs. Small Rumin. Res. 51 243-249.

Solaiman, S., Min, B.R., Gurung, N., Behrends, J., McElhenney, W., 2012. Effects of breed and harvest age on feed intake, growth, carcass traits, blood metabolites, and lipogenic gene expression in Boer and Kiko goats. J. Anim. Sci. 2012 (90), 2092-2108.

Solomon, M., Melaku, S., Tolera, A., 2008. Supplementation of cottonseed meal on feed intake, digestibility, live weight and carcass parameters of Sidama goats. Livest. Sci. 119, 137-144.

Ssewanyana, E., Oluka, J., Masaba, J.K., 2004. Growth and performance of indigenous crossbred goats. Uganda J. Agric. Sci. 9, 537-542.

Tilley, J.M.A., Terry, R.A., 1963. A two-stage technique for the in vitro digestion of forage crops. J. Br. Grassl. Soc. 18, 104-111.

Turner, K.E., Belesky, D.P., Zajac, A.M., Dowd, M.K., 2014. Performance and blood parameters when lambs and meat-goat kids were finished on pasture with and without whole cottonseed (Gossypium hirsutum) supplementation. Grass Forage Sci. http://dx.doi.org/10.1111/gfs.12121.

UBOS (Uganda Bureau of Statistics), 2009. The National Livestock Census report 2008. Final Report, August 2009. 〈www.ubos.org $\rangle$.

Van soest, P.J., Robertson, J.B., Lewis, B.A., 1991. Methods for dietary fiber neutral detergent fiber, and non-starch polysaccharides in relation to animal nutrition. J. Dairy Sci. 74, 3583-3597.

Weisbjerg, M.R., Hvelplund, T., 1993. Bestemmelser af nettoenergiindhold (FEK) i forhold til kvæg. Forskningsrapport nr. 3, StatensHusdyrbrugsforsøg, 39 pp.

Zervas, G., Tsiplakou, E., 2011. The effect of feeding systems on the characteristics of products from small ruminants. Small Rumin. Res $101,140-149$. 